\title{
Spatial Analysis of Seasonal Precipitation Using Various Interpolation Methods in the Euphrates Basin, Turkey
}

Okan Mert Katipoğlu ( $\nabla$ okatipoglu@erzincan.edu.tr)

Erzincan Binali Yildirim University: Erzincan Binali Yildirim Universitesi https://orcid.org/0000-00016421-6087

\section{Research Article}

Keywords: Precipitation, Mapping, Geostatistical Interpolation, Deterministic Interpolation, Kriging, Euphrates Basin

Posted Date: September 27th, 2021

DOI: https://doi.org/10.21203/rs.3.rs-809129/v1

License: (c) (i) This work is licensed under a Creative Commons Attribution 4.0 International License. Read Full License

Version of Record: A version of this preprint was published at Acta Geophysica on March 21st, 2022. See the published version at https://doi.org/10.1007/s11600-022-00756-0. 


\section{Abstract}

It is vital to accurately map the spatial distribution of precipitation, which is widely used in many fields such as hydrology, climatology, meteorology, ecology, and agriculture. In this study, it was aimed to reveal the spatial distribution of seasonal long-term average precipitation in the Euphrates Basin by using various interpolation methods. For this reason, Simple Kriging (SK), Ordinary Kriging (OK), Universal Kriging (UK), Ordinary CoKriging (OCK), Empirical Bayesian Kriging (EBK), Radial Basis Functions (Completely Regularized Spline (CRS), Thin Plate Spline (TPS), Multiquadratic, Inverse Multiquadratic (IM), Spline with Tensor (ST)), Local Polynomial Interpolation (LPI), Global Polynomial Interpolation (GPI), Inverse Distance Weighting (IDW) methods have been applied in the Geographical Information Systems (GIS) environment. Long-term seasonal precipitation averages between 1966 and 2017 are presented as input for the prediction of precipitation maps. The accuracy of the precipitation prediction maps created was based on root mean square error (RMSE) values obtained from the cross-validation tests. The method of precipitation by interpolation yielding the lowest RMSE was selected as the most appropriate method. As a result of the study, OCK in spring and winter precipitation, LPI in summer precipitation, and OK in autumn precipitation were determined as the most appropriate estimation method.

\section{Introduction}

Precipitation is one of the most significant driving forces in the hydrological cycle affecting hydrological processes (Caracciolo et al. 2014; Cheng et al. 2017). Today, precipitation data are mostly obtained from rain gauges, weather radars, and satellites (Price et al. 2014). Although there are various measurement methods, precipitation values measured by rain gauges are seen as more reliable measurements. Precipitation measurement stations provide point precipitation, but studies related to hydrology, climate, agriculture, ecology, and environment require spatial precipitation data (Phillips et al. 1992). Analysis of time and space variability in precipitation is important for the sustainable use of water resources, the management of droughts, water resource management applications such as water budget analysis, flood frequency analysis, rainfall-runoff modeling, and design of hydraulic structures (Adhikary et al. 2015), estimating the amount of surface and underground water resources, conducting studies on pollution of water resources and air pollution (Aydin and Çiçek 2013). In addition, detailed knowledge of the Spatiotemporal distribution of precipitation is needed to accurately model flood control using surface water storage or detention basins using rainwater harvesting systems (Bellu et al. 2016; Malik et al. 2019; Terêncio et al. 2018; Terêncio et al. 2017). Therefore, determining the spatial precipitation change using various interpolation methods is of vital importance.

A sufficient number of observations are needed to characterize the spatial distribution of a particular variable and to map this distribution. However, it is not technically and economically possible to measure environmental variables everywhere in the world or to measure everywhere in a certain region in the world (Aslantaş et al. 2016). Therefore, various spatial interpolation methods have been developed. Spatial interpolation is the process of using known values to estimate values at unknown points. Spatial interpolation can estimate the precipitation value at a location where there is no recorded data, using 
values from known weather stations nearby. Spatial interpolation is based on Tobler's Law of Geography. This law expresses that points in space that are close to each other have more similar values than points that are very far from each other. A spatial interpolation is a tool based on spatial correlation logic to estimate the values of an environmental variable at unsampled points using data from point observations in the same region. This tool, which is widely used in geoinformatics, can be examined in two basic categories: deterministic techniques and geostatistical techniques. While deterministic interpolation methods make use of sampled points and mathematical equations to produce surfaces; In geostatistical methods, estimations are made using the statistical properties of the data (Childs 2004). Spatial interpolation covers a variety of methods including trend surface models, Thiessen Polygons (TP), Natural Neighbor Interpolation (NNI), Polynomial Interpolation (PI), Inverse Distance Weighting (IDW), Splines, and Kriging.

There is no single interpolation method that can be selected for spatial interpolation. The method to be selected may vary depending on various parameters such as data type (precipitation, temperature, streamflow, groundwater, air humidity, soil moisture, air pollution, water pollution, etc.), distribution of data (homogeneous or random). Choosing a suitable spatial interpolation method is crucial for surface analysis because different interpolation methods can create different results (Kamińska and Grzywna 2014).

There are various studies in the literature on determining the spatial distribution of precipitation. As an example to the prominent ones: Vicente-Serrano et al. (2003) analyze the validity of various precipitation and temperature maps obtained employing diverse interpolation methods (Global Interpolation (GI), Local Interpolation (LI), Ordinary Kriging (OK), Simple Kriging (SK), Co-Kriging (CK), Block Kriging (BK), Directional Kriging (DK), Universal Kriging (UK), and mixed methods) in the middle Ebro Valley. Lloyd (2010) applied various Kriging methods to evaluate the change in the spatial structure of precipitation. Bostan et al. (2012) created a spatial distribution map of the average annual precipitation change in Turkey by using many variables such as altitude, aspect, surface roughness, distance to the shore, land use, and ecological regions. Keblouti et al. (2012) used OK, IDW, and spline to reveal spatial interpolation of annual rainfall in Annaba-Algeria. By comparing the error rates, the IDW method was chosen as the most representative method of interpolation to characterize the precipitation distribution. Aydin and Çiçek (2013) used OK and IDW techniques to reveal the spatial pattern of the annual average precipitation of the Aegean Region. Aslantaş et al. (2016) used OK and UK methods to determine the temporal and spatial variation of the annual precipitation values of the Euphrates Basin. Gupta et al. (2017) employed five geostatistical modeling techniques (Exponential Ordinary Kriging (EOK), Gaussian Ordinary Kriging (GOK), Circular Ordinary Kriging (COK), Spherical Ordinary Kriging (SOK), and EBK) to indicate spatial and temporal distributions of the annual rainfall in the north-west of India. Hadi and Tombul (2018) applied IDW, TP, OK, UK, SK, and Local Polynomial Interpolation (LPI) methods to interpolate precipitation and temperature in the Seyhan Basin, Turkey. Kale (2018) applied deterministic and stochastic methods to determine the spatial variation of long-term precipitation in the Yeşilırmak Basin, Turkey. Agou et al. (2019) estimated spatial and temporal patterns of average annual precipitation in the Mediterranean island of Crete using regression kriging (RK) interpolation. Malik et al. (2019) applied the TP to interpolate 
spatial distribution of the trends in seasonal and annual precipitation in India. Khorrami and Gündüz (2019) compared different techniques such as IDW, RBF, Kriging, and CK to reveal the spatial distribution of precipitation in İzmir province and it was found that CK was the most successful. Rata et al. (2020) applied RK, OK, and KED methods to create maps of annual precipitation in the main watershed in Algeria. Katipoglu (2021) used geostatistical interpolation methods to map annual precipitation. According to the results of the analysis, it was understood that the most suitable interpolation model was EBK. The most suitable EBK model used in estimating was obtained with the K-Bessel detrended semivariogram function, the smooth circular neighborhood type, and log empirical transformation, without removing trends. When the available literature is examined, it appeared that the spatial distribution of annual precipitation is generally estimated and a detailed comparison of all interpolation methods is lacking. For this reason, as the subject of the study, the interpolation method that best fits seasonal precipitation has been examined.

Kumar and Jain (2010) stated that the change in precipitation distribution affects the temporal and spatial changes of surface flow, soil moisture, and groundwater reserves and can change the frequency of floods and droughts. Consequently, it is significant to determine changes in trends in the world at spatiotemporal scales. This study aims to compare the capability of 13 different spatial interpolation methods in precipitation prediction. For this purpose, seasonal rainfalls of 17 meteorological observation stations in the Euphrates Basin were used and spatial distribution maps were created by various interpolation methods. In selecting the most suitable interpolation method, the model parameters were tried until the smallest error values were obtained.

\section{Material And Methods}

\subsection{Study area and data}

In this study, monthly average precipitation (1966-2017) and topographic data collected from 21 meteorological stations in and around the Euphrates Basin were used. Data were obtained from the Turkish Meteorology General Directorate. The location map of the meteorological observation stations used in the study is shown in Fig. 1. The topographic data of the stations used are presented in Table 1. 
Table 1

Location information of the stations used in the study

\begin{tabular}{|llll|}
\hline Station & Latitude & Longitude & Altitude \\
\hline Kangal & 39,24 & 37,38 & 1521 \\
\hline Divriği & 39,36 & 38,11 & 1121 \\
\hline Erzincan & 39,75 & 39,48 & 1216 \\
\hline Tercan & 39,78 & 40,39 & 1429 \\
\hline Erzurum & 39,95 & 41,19 & 1758 \\
\hline Hınıs & 39,37 & 41,69 & 1715 \\
\hline Tunceli & 39,11 & 39,54 & 981 \\
\hline Ağrı & 39,72 & 43,05 & 1646 \\
\hline Malazgirt & 39,14 & 42,53 & 1540 \\
\hline Muş & 38,75 & 41,5 & 1322 \\
\hline Solhan & 38,96 & 41,05 & 1366 \\
\hline Arapgir & 39,04 & 38,49 & 1200 \\
\hline Bingöl & 38,88 & 40,5 & 1139 \\
\hline Erciş & 39,02 & 43,34 & 1678 \\
\hline İspir & 40,48 & 40,99 & 1223 \\
\hline Tortum & 40,3 & 41,54 & 1576 \\
\hline Horasan & 40,04 & 42,17 & 1540 \\
\hline Zara & 39,89 & 37,75 & 1338 \\
\hline Adıyaman & 37,75 & 38,28 & 672 \\
\hline Mardin & 37,31 & 40,73 & 1040 \\
\hline Malatya & 38,34 & 38,22 & 950 \\
\hline Hyar & 390,59 \\
\hline
\end{tabular}

In the northern part of the study area, starting from the Malatya Plain, the winter season is generally cold, snowy, and quite long. Frosts are also common. Although the summer season is generally cool, high temperatures are seen in the low areas. In the south of the basin, the summer season is generally very hot and dry, while the winter season is rarely cold. Most of the precipitation is in the winter and spring seasons. The low relative humidity in the region increases the amount of evaporation. In addition, due to the low summer precipitation in the region, a severe and long drought prevails in the summer season (Sensoy et al. 2008). 
The air mass that is effective in the northern parts of the study area in winter is of Siberian origin. Since the autumn months, snowfall begins at high places due to this air mass that enters the region. Since the frontal activities are less in winter, the second dry period is winter. The winter season characterizes the cold anticyclonic weather conditions as the area is far from the sea and the polar air masses affect the area for a long time. The areas in the south are under the influence of the continental tropical air mass, which is very dry and stagnant, mostly resulting from the Basra low pressure in the summer period. This season is very dry and hot for the field (Yurddaş 2008).

\subsection{Interpolation methods}

Interpolation methods help to produce maps for large areas by detecting values for unknown points with the help of known points. Spatial interpolation techniques are gathered in two main groups as deterministic and geostatistical. Deterministic interpolation methods are used to construct a surface using the existing form of the sample points or to fit a mathematical function to the measured points. Geostatistical techniques, on the other hand, create a spatial correlation between the calculated points and the sample points. For geostatistical analysis to be carried out with a proximity relationship, there must be a spatial dependence, a spatial relationship, that is, autocorrelation. Since geostatistical techniques are based on statistics, not only do they produce estimation maps, but also error maps that express the quality of the estimations (Johnston et al. 2001; Kamali et al. 2015). Deterministic techniques, on the other hand, use existing configurations of sample points to construct a surface or place a mathematical function on the measured points.

\subsubsection{Deterministic methods}

\section{Inverse distance weighting (IDW)}

It is a method for estimating cell values of unsampled points through the values of known sample points. The cell value is calculated taking into account various points moving away from the corresponding cell and depending on the distance increment. The estimated values are a function of the distance and size of adjacent points, and the importance and effect on the cell to be estimated decreases as the distance increases. In this method, properties such as general distribution, tendency, anisotropy, and clustering are examined. The data are only evaluated and compared locally (Doğan et al. 2013).

\section{Radial basis functions (RTF)}

Radial basis functions are considered as the exact interpolation method. Exact interpolators estimate the identical values as measured at the same point, and the surface created requires passing through each measured point. The estimated values may vary above the maximum or below the minimum of the measured values (Nikolova and Vassilev 2006). There are five different basic functions: thin-plate spline, spline with tension, completely regularized spline, multiquadric function, and inverse multiquadric spline. Each function has a different shape and results in a different interpolation surface. While there are more 
entry points specified, the greater the influence of distant points and the smoother the surface (Karydas et al. 2009).

\section{Global polynomial interpolation (GPE)}

The GPE method is used to obtain a surface with a polynomial function that covers the entire study area using sample points. This method provides the possibility to create different surfaces for each defined polynomial equation. First-order polynomial equations can be used to generate linear surfaces, secondorder polynomial equations can be used to obtain curved surfaces, and third-order polynomial equations can be used to generate cubic surfaces (Johnston et al. 2001).

\section{Local polynomial interpolation (LPE)}

Unlike the GPE method, the LPE method uses different polynomial equations for different locations of the study area. This method uses sample points within a specified neighborhood search radius.

Neighborhood search diameter is expressed as a circle or ellipse with a certain radius. With the polynomial equations created for each neighborhood search diameter obtained, an estimate is made from the values of the neighboring points for the point in the center of this neighborhood boundary.

\subsubsection{Geostatistical methods}

\section{Kriging}

The kriging interpolation method is an interpolation method that estimates the optimum values of data at other points by using data from known close points. Kriging interpolation is a method in which unbiased estimation of spatial changes at unsampled points is optimally made using semivariogram structural features. The most important feature that distinguishes the Kriging method from other interpolation methods is that a variance value can be calculated for each predicted point or area (Taylan and Damçayırı 2016). The basic equation used in Kriging is as in Eq. 1.

$\mathrm{N}_{\mathrm{p}}=\sum_{i}^{n} P_{i} x N_{i}$

$\mathrm{n}$ : the number of points forming the model,

$N_{i}$ : geoid ondulation values of the points used in the calculation of $N_{p}$,

$\mathrm{N}_{\mathrm{p}}$ : the sought ondulation value,

$\mathrm{P}_{\mathrm{i}}$ : the weight value corresponding to each $\mathrm{N}_{\mathrm{i}}$ value used in the calculation of $\mathrm{N}$.

\section{Empirical bayesian kriging (EBK)}

EBK differs from conventional kriging methods by considering the error associated with the estimation of the semi-variogram model. This is accomplished by estimating and using multiple semivariogram 
models instead of a single semivariogram. This process consists of the following stages:

- A model of semivariograms is estimated from the data.

- By using this semivariogram, a new value is simulated in each input data location.

- Simulation data provide an estimate of a new semivariogram model. A weight for this semivariogram is then computed using the Bayes rule, which indicates the probability of the observed data being created from the semivariogram (Krivoruchko 2012).

\subsection{Cross-validation test}

The Cross-validation method, which is one of the most frequently used methods to specify the accuracy of predictive models, examines the relationship between the predicted and measurement values by using the available information in the sample data set. In this method, the value at a location is temporarily extracted from the data set and an estimation process is done for this extracted location using the remaining values. This process is also repeated for all remaining samples (Isaaks and Srivastava 1989). Various error measurement methods can be used in the evaluation of estimation maps. In this study, the most preferred statistical criterion, root mean square errors (RMSE) values are used to evaluate model performance. This value is calculated as in Eq. 2.

$\mathrm{RMSE}=\sqrt{\frac{1}{N} \sum_{\mathrm{I}=1}^{N}\left(x_{i}-y_{i}\right)^{2}}$

Here; $x_{i}$, expected values of models, $y_{i}$, the estimation values, $N$ : the number of data. The model which the lowest error rates (close to 0 ) are evaluated as the best.

\section{Results And Discussion}

In this study, the performance of various deterministic and geostatistical methods in mapping seasonal precipitation in the Euphrates Basin was compared. Monthly total precipitation data of 21 meteorological observation stations covering the years 1966 to 2017 were used to establish the model. Cross-validation tests were used for the performance evaluation of the model. The model that gave the smallest RMSE value obtained as a result of the cross-validation test was selected as the most successful.

\subsection{Spatial mapping in spring rainfall data series}

In this part of the study, a spatial map of the long-term seasonal average precipitation was produced using 13 different interpolation methods. In the selection of the most appropriate interpolation method, various model parameters such as transform, trend, kernel function, semi-variogram, sector type, power parameter, order of the polynomial, and neighborhood type were tested by trial and error method and the parameters with the smallest error rate were applied. According to the results of the comparison, the most suitable estimator algorithm was found to be OCK (Table 2-4). 
Table 2

Geostatistical (kriging) interpolation results of spring precipitation

Kriging

\begin{tabular}{|c|c|c|c|c|c|}
\hline & $\begin{array}{l}\text { Ordinary } \\
\text { Kriging }\end{array}$ & $\begin{array}{l}\text { Simple } \\
\text { Kriging }\end{array}$ & $\begin{array}{l}\text { Universal } \\
\text { Kriging }\end{array}$ & $\begin{array}{l}{ }^{\star *} \text { Ordinary } \\
\text { CoKriging }\end{array}$ & $\begin{array}{l}\text { Empirical } \\
\text { Bayesian Kriging }\end{array}$ \\
\hline Transform & - & Log & - & - & - \\
\hline $\begin{array}{l}\text { Trend } \\
\text { removal }\end{array}$ & - & Second-order & Constant & - & - \\
\hline $\begin{array}{l}\text { Kernel } \\
\text { function }\end{array}$ & - & Epanechnikov & Exponantial & - & - \\
\hline $\begin{array}{l}\text { Semi } \\
\text { variogram }\end{array}$ & $\begin{array}{l}\text { Hole } \\
\text { effect }\end{array}$ & J-Bessel & J-Bessel & Hole effect & Power \\
\hline Sector type & - & 8 Sector & $\begin{array}{l}4 \text { Sector with } \\
45^{0} \text { offset }\end{array}$ & $\begin{array}{l}4 \text { Sector with } \\
45^{0} \text { offset }\end{array}$ & - \\
\hline $\begin{array}{l}\text { Neigborhood } \\
\text { type }\end{array}$ & Smooth & Standard & Standard & Standard & Smooth Circular \\
\hline RMSE & 35,84 & 47,02 & 37,87 & 34,93 & 38,75 \\
\hline
\end{tabular}

Table 4

Other deterministic interpolation results of spring precipitation

$\begin{array}{lll}\text { Local Polynomial } & \text { Global Polynomial } & \begin{array}{l}\text { Inverse Distance } \\ \text { Interpolation }\end{array} \\ \text { Interpolation } & \text { Weighting }\end{array}$

Power

parameter

Order of

polynomial

Kernel function Constant

\section{Interpolation}

2,42

2

Sector type $\quad 1$ Sector

Neighborhood Standard

type

RMSE

42,34

49,94

44,75

4 Sector with $45^{0}$

offset

Standard

The geostatistical model giving the lowest RMSE (34.93) value in the prediction of spring precipitation was revealed as OCK with hole effect semi-variogram distribution (Table 2). When the spring precipitation prediction success of the RTF models is compared, it is noteworthy that the spline with the tensor model 
is the most effective with the smallest RMSE (41.43) value (Table 3). It was also revealed that the prediction success of LPI, GPI, and IDW models is relatively low (Table 4).

Table 3

Deterministic (Radial Basis Function) interpolation results of spring precipitation

\begin{tabular}{|c|c|c|c|c|c|}
\hline & \multicolumn{5}{|c|}{ Radial Basis Function } \\
\hline & Completely & Thin Plate & Multiquadratic & Inverse & Spline with \\
\hline & $\begin{array}{l}\text { Regularized } \\
\text { Spline }\end{array}$ & & & & \\
\hline Sector type & 1 Sector & 1 Sector & 1 Sector & 8 Sector & 1 Sector \\
\hline $\begin{array}{l}\text { Neighborhood } \\
\text { type }\end{array}$ & Standard & Standard & Standard & Standard & Standard \\
\hline RMSE & 41,94 & 57,49 & 41,84 & 42,16 & 41,43 \\
\hline
\end{tabular}

Simple interpolation methods do not take into account the effects of topography on precipitation and can make significant mistakes in mountainous regions. For this reason, the OCK method in which altitude values are presented to the model as an auxiliary variable was also used in the study. When the interpolation methods of the first spring precipitation are compared, it is seen that the most effective predictions are obtained by the OCK method. The most suitable OCK model used in estimating was obtained with the Hole effect semivariogram function and the standard neighborhood type, without applying a transformation to rainfall data or removing trends (Table 2-4).

The spatial variation map of the long-term precipitation averages of the spring season is presented in Fig. 2. Based on the spatial variation map, it was noted that the least precipitation occurred in the Kangal, Tercan, Tortum, Erzurum, and Tercan precipitation stations located in the north and northwest of the Euphrates Basin and this value was approximately between 148 and $183 \mathrm{~mm}$. It has been determined that the amount of precipitation increases from the north to the south of the basin and the most precipitation falls in Bingöl and its surroundings, which are located in the inner parts of the basin.

\subsection{Spatial mapping in summer rainfall data series}

Various interpolation methods have been used for mapping summer precipitation. Interpolation parameters were tested to reveal the most successful predictive model. As a result of model comparisons, it was seen that LPI was the most effective model with the smallest error (Table 5-7). 
Table 5

Geostatistical (kriging) interpolation results of summer precipitation

\section{Kriging}

\begin{tabular}{|c|c|c|c|c|c|}
\hline & $\begin{array}{l}\text { Ordinary } \\
\text { Kriging }\end{array}$ & Simple Kriging & $\begin{array}{l}\text { Universal } \\
\text { Kriging }\end{array}$ & $\begin{array}{l}\text { Ordinary } \\
\text { CoKriging }\end{array}$ & $\begin{array}{l}\text { Empirical } \\
\text { Bayesian Kriging }\end{array}$ \\
\hline Transform & - & Normal score & - & Log & Log empirical \\
\hline $\begin{array}{l}\text { Trend } \\
\text { removal }\end{array}$ & - & Second-order & Constant & Second-order & - \\
\hline $\begin{array}{l}\text { Kernel } \\
\text { function }\end{array}$ & - & Quartic & Exponential & Polynomial5 & - \\
\hline $\begin{array}{l}\text { Semi } \\
\text { variogram }\end{array}$ & J-Bessel & J-Bessel & Gaussian & J-Bessel & $\begin{array}{l}\text { Exponential } \\
\text { detrended }\end{array}$ \\
\hline Sector type & - & $\begin{array}{l}4 \text { Sector with } \\
45^{0} \text { offset }\end{array}$ & $\begin{array}{l}4 \text { Sector with } \\
45^{0} \text { offset }\end{array}$ & $\begin{array}{l}4 \text { Sector with } \\
45^{0} \text { offset }\end{array}$ & - \\
\hline $\begin{array}{l}\text { Neigborhood } \\
\text { type }\end{array}$ & Smooth & Standard & Standard & Standard & Standard Circular \\
\hline RMSE & 11,64 & 12,61 & 12,09 & 11,74 & 11,06 \\
\hline
\end{tabular}

Table 7

Other deterministic interpolation results of summer precipitation

\begin{tabular}{|llll|}
\hline & $\begin{array}{l}\text { **Local Polynomial } \\
\text { Interpolation }\end{array}$ & $\begin{array}{l}\text { Global Polynomial } \\
\text { Interpolation }\end{array}$ & $\begin{array}{l}\text { Inverse Distance } \\
\text { Weighting }\end{array}$ \\
\hline $\begin{array}{l}\text { Power } \\
\text { parameter }\end{array}$ & - & - & 3,94 \\
\hline $\begin{array}{l}\text { Order of } \\
\text { polynomial }\end{array}$ & 2 & - & - \\
\hline Kernel function & Quartic & - & 8 Sector \\
\hline Sector type & 1 Sector & - & Standard \\
\hline $\begin{array}{l}\text { Neighborhood } \\
\text { type }\end{array}$ & Standard & - & 15,25 \\
\hline RMSE & 10,68 & 16,24 & \\
\hline Note: The & ** sign indicates the most appropriate interpolation method. \\
\hline
\end{tabular}

The geostatistical model indicating the lowest RMSE $(11,64)$ value in the prediction of summer precipitation was revealed as OK with J-Bessel semi-variogram distribution (Table 5). When the summer precipitation prediction success of the RTF models is analyzed, it is significant that the multiquadratic 
model is the most effective with the smallest RMSE $(11,37)$ value (Table 6). It was also seen that the LPI model is the most successful deterministic model (Table 7).

Table 6

Deterministic (Radial Basis Function) interpolation results of summer precipitation

\begin{tabular}{|c|c|c|c|c|c|}
\hline & \multicolumn{5}{|c|}{ Radial Basis Function } \\
\hline & Completely & Thin Plate & Multiquadratic & Inverse & Spline with \\
\hline & $\begin{array}{l}\text { Regularized } \\
\text { Spline }\end{array}$ & & & viurtiquauratic & IEIISOI \\
\hline Sector type & 4 Sector & 1 Sector & $\begin{array}{l}4 \text { Sector with } \\
45^{0} \text { off set }\end{array}$ & - & 8 Sector \\
\hline $\begin{array}{l}\text { Neighborhood } \\
\text { type }\end{array}$ & Standard & Standard & Standard & Smooth & Standard \\
\hline RMSE & 12,18 & 12,00 & 11,37 & 12,66 & 12,04 \\
\hline
\end{tabular}

When the RMSE statistics obtained as a result of the cross-validation test were compared, it was determined that the most accurate estimations for the summer rainfall estimation were obtained with the LPI method. The most suitable Local Polynomial model used in estimating was obtained with the Quartic semivariogram function, the standard neighborhood type, and 1 st order polynomial (Table 5-7).

The spatial variation map of the long-term precipitation averages of the summer season is given in Fig. 3 . When the spatial variation map of summer precipitation is examined, it is seen that the least precipitation occurs in Adiyaman and Mardin precipitation observation stations located in the south of the Euphrates Basin and this value is approximately between 11 and $21 \mathrm{~mm}$. It has been determined that the amount of precipitation increases from the south to the north of the basin and the highest precipitation falls to the İspir, Tortum, Erzurum, and Horasan stations located in the north of the basin.

\subsection{Spatial mapping in autumn rainfall data series}

Various deterministic and geostatistical methods have been used to determine the spatial variation map of autumn precipitation. Various model parameters were tried to find the most successful estimator. As a result, the best model with the smallest error was chosen as the Ordinary Kriging method (Table 8-10). 
Table 8

Geostatistical (kriging) interpolation results of autumn precipitation

\section{Kriging}

\begin{tabular}{|c|c|c|c|c|c|}
\hline & $\begin{array}{l}{ }^{* *} \text { Ordinary } \\
\text { Kriging }\end{array}$ & $\begin{array}{l}\text { Simple } \\
\text { Kriging }\end{array}$ & $\begin{array}{l}\text { Universal } \\
\text { Kriging }\end{array}$ & $\begin{array}{l}\text { Ordinary } \\
\text { CoKriging }\end{array}$ & $\begin{array}{l}\text { Empirical } \\
\text { Bayesian } \\
\text { Kriging }\end{array}$ \\
\hline Transform & - & - & Box-Cox & - & Log empirical \\
\hline $\begin{array}{l}\text { Trend } \\
\text { removal }\end{array}$ & - & - & Constant & - & - \\
\hline $\begin{array}{l}\text { Kernel } \\
\text { function }\end{array}$ & - & - & Exponential & - & \\
\hline $\begin{array}{l}\text { Semi } \\
\text { variogram }\end{array}$ & J-Bessel & J-Bessel & J-Bessel & Hole effect & K-bessel \\
\hline Sector type & $\begin{array}{l}4 \text { Sector with } \\
45^{0} \text { offset }\end{array}$ & $\begin{array}{l}4 \text { Sector with } \\
45^{0} \text { offset }\end{array}$ & $\begin{array}{l}4 \text { Sector with } \\
45^{0} \text { offset }\end{array}$ & $\begin{array}{l}4 \text { Sector with } \\
45^{0} \text { offset }\end{array}$ & - \\
\hline $\begin{array}{l}\text { Neigborhood } \\
\text { type }\end{array}$ & Standard & Standard & Standard & Standard & $\begin{array}{l}\text { Standart } \\
\text { Circular }\end{array}$ \\
\hline RMSE & 24,65 & 24,85 & 25,88 & 24,91 & 25,68 \\
\hline
\end{tabular}

Table 10

Other deterministic interpolation results of autumn precipitation

$\begin{array}{lll}\text { Local Polynomial } & \text { Global Polynomial } & \begin{array}{l}\text { Inverse Distance } \\ \text { Weighting }\end{array}\end{array}$

Power

parameter

Order of

polynomial

Kernel function Gaussian

Sector type $\quad 1$ Sector

Neighborhood Standard

type

RMSE
1
1,25

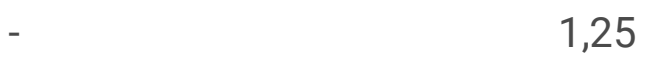

2

Smooth

37,37

31,98

It is seen that the geostatistical model with the lowest RMSE $(24,65)$ value in the prediction of autumn precipitation is OK with the J-Bessel semi-variogram model (Table 8). When the autumn precipitation predicting the success of the RTF models is examined, the Spline with Tensor model was found to be the 
most effective with the smallest RMSE $(28,04)$ value (Table 9). In addition, it was found that the prediction success of LPI, GPI, and IDW models is relatively low (Table 10).

Table 9

Deterministic (Radial Basis Function) interpolation results of autumn precipitation

\begin{tabular}{|c|c|c|c|c|c|}
\hline & Radial Basis & iction & & & \\
\hline & Completely & Thin Plate & Multiquadratic & Inverse & Spline with \\
\hline & $\begin{array}{l}\text { Regularized } \\
\text { Spline }\end{array}$ & spminte & & IMuitiquadratic & Tensor \\
\hline Sector type & 8 Sector & 1 Sector & 1 Sector & 8 Sector & 8 Sector \\
\hline $\begin{array}{l}\text { Neighborhood } \\
\text { type }\end{array}$ & Standard & Standard & Standard & Standard & Standard \\
\hline RMSE & 28,14 & 41,56 & 30,38 & 28,48 & 28,04 \\
\hline
\end{tabular}

When the RMSE statistics obtained as a result of the cross-validation test were compared, it was determined that the most accurate estimations for the autumn rainfall estimation were obtained with the OK method. The most suitable OK model used in estimating was obtained with the J-Bessel semivariogram function and the smooth neighborhood type, without applying conversion to rainfall data or removing trends (Table 8-10).

The spatial variation map of the long-term precipitation averages of the autumn season is presented in Fig. 4. Based on the spatial variation map, it is seen that the least precipitation occurs in the Kangal, İspir, Tortum, and Erzurum precipitation stations located in the north and northwest of the Euphrates Basin, and this value is approximately between 82 and $103 \mathrm{~mm}$. It has been determined that the amount of precipitation generally increases from the north to the south of the basin and the most precipitation falls in Bingöl and its surroundings, which are located in the inner parts of the basin.

\subsection{Spatial mapping in winter rainfall data series}

Various interpolation methods have been used for mapping winter precipitation. Various model parameters were tested to reveal the most successful predictive model. As a result of model comparisons, it was seen that OCK was the most effective model with the smallest error (Table 11-13). 
Table 11

Geostatistical (kriging) interpolation results of winter precipitation

Kriging

\begin{tabular}{|c|c|c|c|c|c|}
\hline & $\begin{array}{l}\text { Ordinary } \\
\text { Kriging }\end{array}$ & Simple Kriging & $\begin{array}{l}\text { Universal } \\
\text { Kriging }\end{array}$ & $\begin{array}{l}\star \star \text { Ordinary } \\
\text { CoKriging }\end{array}$ & $\begin{array}{l}\text { Empirical } \\
\text { Bayesian Kriging }\end{array}$ \\
\hline Transform & Log & Normal score & - & - & Log empirical \\
\hline $\begin{array}{l}\text { Trend } \\
\text { removal }\end{array}$ & - & - & Constant & - & - \\
\hline $\begin{array}{l}\text { Kernel } \\
\text { function }\end{array}$ & - & - & Exponential & - & \\
\hline $\begin{array}{l}\text { Semi } \\
\text { variogram }\end{array}$ & J-Bessel & Stable & J-Bessel & J-Bessel & $\begin{array}{l}\text { K-Bessel } \\
\text { Detrended }\end{array}$ \\
\hline Sector type & & $\begin{array}{l}4 \text { Sector with } \\
45^{0} \text { off set }\end{array}$ & - & $\begin{array}{l}4 \text { Sector with } \\
45^{0} \text { offset }\end{array}$ & - \\
\hline $\begin{array}{l}\text { Neigborhood } \\
\text { type }\end{array}$ & Smooth & Standard & Smooth & Standard & Standart Circular \\
\hline RMSE & 87,78 & 98,25 & 86,32 & 81,62 & 81,75 \\
\hline
\end{tabular}

Table 13

Other deterministic interpolation results of winter precipitation

$\begin{array}{lll}\text { Local Polynomial } & \text { Global Polynomial } & \text { Inverse Distance } \\ \text { Interpolation } & \text { Interpolation } & \text { Weighting }\end{array}$

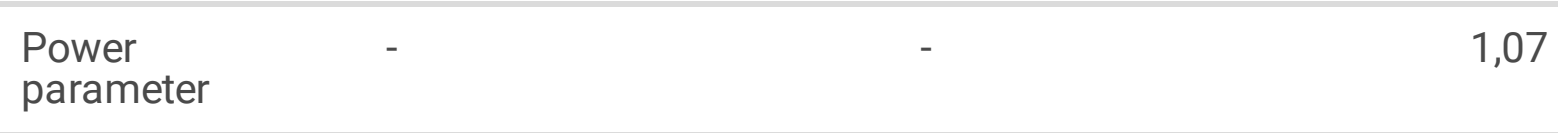

$\begin{array}{lll}\text { Order of } & 1 \\ \text { polynomial } & \end{array}$

\begin{tabular}{|llll|} 
Kernel function & Exponential & - & - \\
\hline Sector type & 1 Sector & - & 1 Sector \\
$\begin{array}{l}\text { Neighborhood } \\
\text { type }\end{array}$ & Standard & - & Standard \\
RMSE & 89,67 & 89,33 & 101,30 \\
\hline
\end{tabular}

It is concluded that the geostatistical model with the lowest RMSE $(81,62)$ value in the prediction of winter precipitation is OCK with the J-Bessel semi-variogram model (Table 11). When the winter precipitation estimation success of the RTF models is compared, the Completely Regularized Spline model was found to be the most forceful with the smallest RMSE $(96,42)$ value (Table 12). In addition, it 
was concluded that the prediction success of LPI and GPI models is relatively higher than RBF and IDW (Table 13).

\section{Table 12}

Deterministic (Radial Basis Function) interpolation results of winter precipitation

\begin{tabular}{|c|c|c|c|c|c|}
\hline & \multicolumn{5}{|c|}{ Radial Basis Function } \\
\hline & Completely & Thin Plate & Multiquadratic & Inverse & Spline with \\
\hline & $\begin{array}{l}\text { Regularized } \\
\text { Spline }\end{array}$ & गріाте & & Trutriquanatic & Tentso \\
\hline Sector type & 4 Sector & 1 Sector & 8 Sector & 1 Sector & 4 Sector \\
\hline $\begin{array}{l}\text { Neighborhood } \\
\text { type }\end{array}$ & Standard & Standard & Standard & Standard & Standard \\
\hline RMSE & 96,42 & 126,5 & 98,77 & 98,70 & 96,56 \\
\hline
\end{tabular}

When the RMSE statistics obtained as a result of the cross-validation test were compared, it was determined that the most accurate estimations for the winter rainfall estimation were obtained with the OCK method. The most suitable OCK model used in estimating was obtained with the J-Bessel semivariogram function and the smooth neighborhood type, without applying conversion to rainfall data or removing trends (Table 11-13).

The spatial variation map of the long-term precipitation averages of the winter season is given in Fig. 5 . According to the spatial variation map, it is seen that the least precipitation occurs in Kangal, İspir, Tortum, Erzurum, Horasan, Ağrı, Hınıs, and Malazgirt precipitation observation stations located in the northeast and northwest of the Euphrates Basin, and this value is approximately between 63 and 130 $\mathrm{mm}$. It has been determined that the amount of precipitation generally increases from the north to the south of the basin and the most precipitation falls around Bingöl, Tunceli, and Adıyaman.

Lloyd (2005) found that the success of precipitation estimation increased due to the use of altitude values as a secondary variable in the interpolation technique. Di Piazza et al. (2011) indicated that taking into account the altitude values in the precipitation estimation will increase the accuracy of the estimation. Khorrami and Gündüz (2019) stated that the geostatistical OCK method is the best interpolator to predict the spatial distribution of precipitation in and around İzmir. In addition, it is predicted that the inclusion of the land topography as an auxiliary variable in the precipitation distribution estimations can greatly improve the prediction quality. In the present study, the successful predictions of the OCK interpolation method, in which the altitude values are taken into account, especially in the spring and winter seasons, support the existing literature.

Keblouti et al. (2012) used OK, IDW, and spline methods to map annual rainfall in Annaba-Algeria which contains a low rainfall network density. As a result, it has been determined that the most successful method is IDW. Keblouti et al. (2012)'s study is inconsistent with the results of the present study. This 
situation is struck by the fact that the stations have a fairly large number and homogeneous distribution in the study carried out.

Ilker (2012) used IDW, Kriging, and Spline interpolation techniques to reveal the spatial distribution of precipitation in the Mediterranean Region. As a result of the analyzes, it was concluded that the IDW interpolation method gave appropriate results in precipitation estimation in general. The study of Ilker (2012) contradicts our study. The reason for this is that precipitation mapping is done using deterministic methods such as IDW since the land structure of the Mediterranean region is flat. However, since the Euphrates Basin has a mountainous structure, precipitation shows sudden spatial variability, and methods such as IDW are insufficient. For this reason, the Euphrates Basin has been mapped more successfully with geostatistical models.

Aslantaş et al. (2016) space-time OK and space-time UK methods are applied to total annual observations for the period of 1970-2008. The OK method gave better results in terms of RMSE and Rsquared statistical indicators than the UK method. Kale (2018) used IDW and Kriging methods to reveal the spatial distribution of long-term precipitation in the Yeşilırmak Basin. It was noted that OK gave better results than the estimates made with IDW. It is seen that the existing literature overlaps with the study.

\section{Conclusions}

This article presents a comprehensive review of determining the spatial distribution of seasonal long-term precipitation averages using deterministic and geostatistical interpolation methods in the Euphrates Basin, Turkey. In the study, precipitation data from 21 meteorological observation stations covering the years 1966 to 2017 were used. The main results of the study can be presented as follows:

- In the creation of precipitation maps in various periods, geostatistical methods produce more accurate estimates than deterministic methods.

- The OCK, LPI, OK, and OCK methods are the most successful interpolation methods in modeling the spatial distribution of precipitation in the spring, summer, autumn, and winter seasons, respectively, since they have the smallest RMSE values.

- Due to the mountainous nature of the basin, it was concluded that the OCK method, which included the height values as a secondary variable in the model, was more successful.

- The OCK method produces more successful predictions in the seasons such as spring and winter, where the difference between the maximum and minimum precipitation values is greatest.

- The J-Bessel, K-Bessel Detrended, and Hole effect semi-variogram functions produced successful results in precipitation forecasting.

- The precipitation in the basin varies between spring (148 and $323 \mathrm{~mm})$, summer (11 and $118 \mathrm{~mm}$ ), autumn ( 82 and $187 \mathrm{~mm}$ ), and winter ( 63 and $396 \mathrm{~mm}$ ). Widening the difference between the maximum and minimum precipitation values increases the prediction errors. 
The creation of spatial maps depends on the number, distribution, and data diversity of meteorological stations in the study area. To achieve better results, it is recommended to develop a meteorological observation network, to get help from remote sensing techniques, and to include different meteorological and topographic variables in the model.

\section{Declarations}

Acknowledgments The author thanks the General Directorate of Meteorology for the observed monthly total precipitation data provided, the Editor, and the anonymous reviewers for their contributions to the content and development of this document.

Author contribution The entire work was solely undertaken by the sole author.

Data Availability Not applicable.

Code availability Not applicable.

Funding No funding was received for conducting this study.

Ethical Approval Not applicable.

Consent to Publish The author confirms that the work described has not been published before, and it is not under consideration for publication elsewhere.

Consent for participate Not applicable.

Conflicts of interest/Competing Interests The author declares no conflict of interest.

\section{References}

1. Adhikary SK, Yilmaz AG, Muttil N (2015) Optimal design of rain gauge network in the Middle Yarra River catchment. Australia Hydrological processes 29:2582-2599. https://doi.org/10.1002/hyp.10389

2. Agou VD, Varouchakis EA, Hristopulos DT (2019) Geostatistical analysis of precipitation in the island of Crete (Greece) based on a sparse monitoring network Environmental. Monitoring Assessment 191:353. doi:10.1007/s10661-019-7462-8. https://doi.org/10.1007/s10661-019-7462-8

3. Aslantaş P, Akyürek Z, Heuvelink G (2016) Yağışın zaman ve mekânda dağılımının elde edilmesi/Obtaining the distribution of precipitation over time and space Dicle University Engineering Faculty. J Eng 7:257-269

4. Aydin O, Çiçek i (2013) Spatial distribution of precipitation in Aegean Region Turkish journal of geographical sciences 11:101-120. https://doi.org/10.1501/Cogbil_0000000145 
5. Bellu A, Fernandes LFS, Cortes RM, Pacheco FA (2016) A framework model for the dimensioning and allocation of a detention basin system: The case of a flood-prone mountainous watershed. J Hydrol 533:567-580. https://doi.org/10.1016/j.jhydrol.2015.12.043

6. Bostan P, Heuvelink GB, Akyurek S (2012) Comparison of regression and kriging techniques for mapping the average annual precipitation of Turkey. International Journal of Applied Earth Observation Geoinformation 19:115-126. https://doi.org/10.1016/j.jag.2012.04.010

7. Caracciolo D, Arnone E, Noto LV (2014) Influence of spatial precipitation sampling on hydrological response at the catchment scale. J Hydrol Eng 19:544-553. https://doi.org/10.1061/(ASCE)HE.1943-5584.0000829

8. Cheng M, Wang Y, Engel B, Zhang W, Peng H, Chen X, Xia H (2017) Performance assessment of spatial interpolation of precipitation for hydrological process simulation in the Three. Gorges Basin Water 9:838. https://doi.org/10.3390/w9110838

9. Childs CJA, July-September (2004) Interpolating surfaces in ArcGIS. spatial analyst 3235:32-35

10. Di Piazza A, Conti FL, Noto LV, Viola F, La Loggia G (2011) Comparative analysis of different techniques for spatial interpolation of rainfall data to create a serially complete monthly time series of precipitation for Sicily, Italy International Journal of Applied Earth Observation Geoinformation 13:396-408. https://doi.org/10.1016/j.jag.2011.01.005

11. Doğan HM, Yılmaz DS, Kılıç OM (2013) Mapping and interpreting some soil surface properties of central kelkit basin by inverse distance weighted (IDW) method Journal of Gaziosmanpasa Scientific Research:46-54. https://doi.org/10.1080/01431161.2013.796097

12. Gupta A, Kamble T, Machiwal D (2017) Comparison of ordinary and Bayesian kriging techniques in depicting rainfall variability in arid and semi-arid regions of north-west India. Environ Earth Sci 76:116. https://doi.org/10.1007/s12665-017-6814-3

13. Hadi SJ, Tombul M (2018) Comparison of spatial interpolation methods of precipitation and temperature using multiple integration periods. journal of the Indian Society of Remote Sensing 46:1187-1199. https://doi.org/10.1007/s12524-018-0783-1

14. Ilker A (2012) Spatial distribution of rainfall in the Mediterranean region. Master's thesis, Suleyman Demirel University Graduate School of Natural and Applied Sciences

15. Isaaks EH, Srivastava MR (1989) An Introduction to Applied Geostatistics. vol 551.72 ISA. Oxford University Press, New York

16. Johnston K, Ver Hoef JM, Krivoruchko K, Lucas N (2001) Using ArcGIS geostatistical analyst, vol 380. Esri Redlands

17. Kale M, M (2018) Determination of Changing Spatial Distribution of Precipitation With Deterministic and Stochastic Methods in Yeşilırmak. Basin Bulletin of the Earth Sciences Application Research Centre of Hacettepe University 39:263-276. https://doi.org/10.17824/yerbilimleri.503952

18. Kamali MI, Nazari R, Faridhosseini A, Ansari H, Eslamian S (2015) The determination of reference evapotranspiration for spatial distribution mapping using geostatistics. Water Resour Manage 29:3929-3940. https://doi.org/10.1007/s11269-015-1037-4 
19. Kamińska A, Grzywna A (2014) Comparison of deteministic interpolation methods for the estimation of groundwater level. Journal of Ecological Engineering 15:55-60. https://doi.org/10.12911/22998993.1125458

20. Karydas CG, Gitas IZ, Koutsogiannaki E, Lydakis-Simantiris N, Silleos G (2009) Evaluation of spatial interpolation techniques for mapping agricultural topsoil properties in Crete EARSeL eProceedings 8:26-39

21. Katipoglu O (2021) Estimating the distribution of average annual precipitation in the Euphrates basin through geostatistical interpolation. methods International Congress of Engineering Sciences and Multidisciplinary Approaches

22. Keblouti M, Ouerdachi L, Boutaghane $H$ (2012) Spatial interpolation of annual precipitation in Annaba-Algeria-comparison and evaluation of methods. Energy Procedia 18:468-475. https://doi.org/10.1016/j.egypro.2012.05.058

23. Khorrami B, Gündüz O (2019) Aylık ortalama yağış için jeoistatistiksel interpolasyon tekniklerine dayalı geliştirilmiş mekansal varyasyon deseni: İzmir-Türkiye'den örnek bir çalışma: Developed spatial variation pattern based on geostatistical interpolation techniques for monthly average precipitation: A case study from Izmir-Turkey 10. National Hydrology Congress Muğla, Turkey

24. Krivoruchko K (2012) Empirical bayesian kriging ArcUser Fall 6

25. Kumar V, Jain SK (2010) Rainfall trend in Ganga-Brahmputra-Meghna river basins of India (19512004). Hydrol J 33:59-66

26. Lloyd C (2005) Assessing the effect of integrating elevation data into the estimation of monthly precipitation in Great Britain. J Hydrol 308:128-150. https://doi.org/10.1016/j.jhydrol.2004.10.026

27. Lloyd C (2010) Nonstationary models for exploring and mapping monthly precipitation in the United Kingdom. International Journal of Climatology: A Journal of the Royal Meteorological Society 30:390-405. https://doi.org/10.1002/joc.1892

28. Malik A, Kumar A, Guhathakurta P, Kisi O (2019) Spatial-temporal trend analysis of seasonal and annual rainfall (1966-2015) using innovative trend analysis method with significance test Arabian. J Geosci 12:1-23. https://doi.org/10.1007/s12517-019-4454-5

29. Nikolova N, Vassilev S Mapping precipitation variability using different interpolation methods. In: Proceedings of the conference on water observation and information system for decision support (BALWOIS) (2006) pp 25-29

30. Phillips DL, Dolph J, Marks D (1992) A comparison of geostatistical procedures for spatial analysis of precipitation in mountainous terrain. Agriculturalforest meteorology 58:119-141. https://doi.org/10.1016/0168-1923(92)90114-J

31. Price K, Purucker ST, Kraemer SR, Babendreier JE, Knightes CD (2014) Comparison of radar and gauge precipitation data in watershed models across varying spatial and temporal scales. Hydrol Process 28:3505-3520. https://doi.org/10.1002/hyp.9890

32. Rata M, Douaoui A, Larid M, Douaik A (2020) Comparison of geostatistical interpolation methods to map annual rainfall in the Chéliff watershed. Algeria Theoretical Applied Climatology 141:1009- 
1024. https://doi.org/10.1007/s00704-020-03218-z

33. Sensoy S, Demircan M, Alan I Trends in Turkey climate extreme indices from 1971 to 2004. In: Third International Conference BALWOIS, 2008

34. Taylan ED, Damçayırı D (2016) The prediction of precipitations of ısparta region by using IDW and Kriging Technical journal 27:7551-7559

35. Terêncio D, Fernandes LS, Cortes R, Moura J, Pacheco F (2018) Rainwater harvesting in catchments for agro-forestry uses: A study focused on the balance between sustainability values and storage capacity. Sci Total Environ 613:1079-1092. https://doi.org/10.1016/j.scitotenv.2017.09.198

36. Terêncio D, Fernandes LS, Cortes R, Pacheco F (2017) Improved framework model to allocate optimal rainwater harvesting sites in small watersheds for agro-forestry uses. Journal of hydrology 550:318330. https://doi.org/10.1016/j.jhydrol.2017.05.003

37. Vicente-Serrano SM, Saz-Sánchez MA, Cuadrat JM (2003) Comparative analysis of interpolation methods in the middle Ebro Valley (Spain): application to annual precipitation and temperature. Climate research 24:161-180. https://doi.org/10.3354/cr024161

38. Yurddaş K (2008) Precipitation and temperature changes and trends in Firat basin Master's thesis, Kahramanmaraş Sutcu Imam University Institute of Social Sciences Kahramanmaraş, Turkey

\section{Figures}




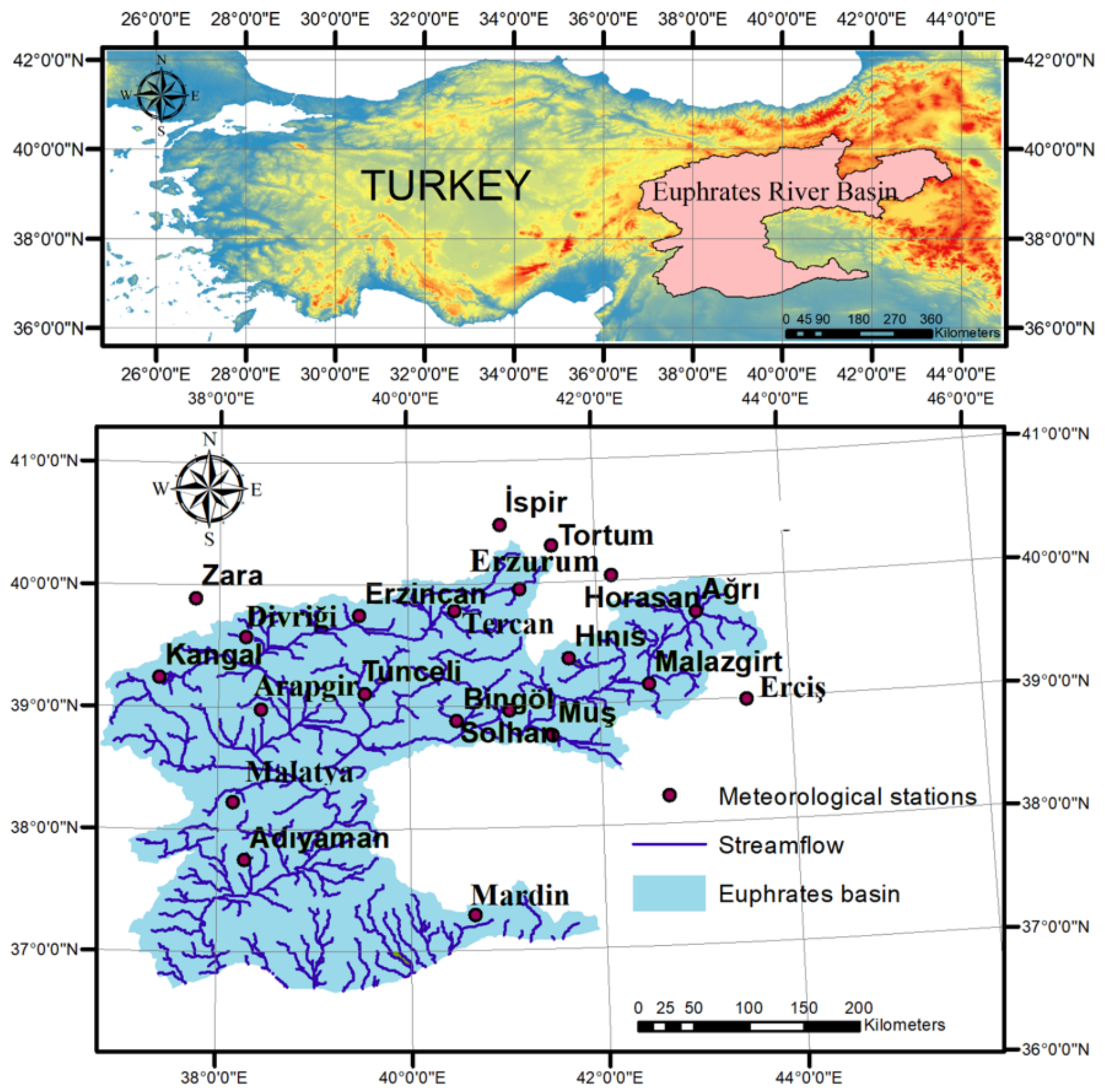

Figure 1

Location map of the study area 


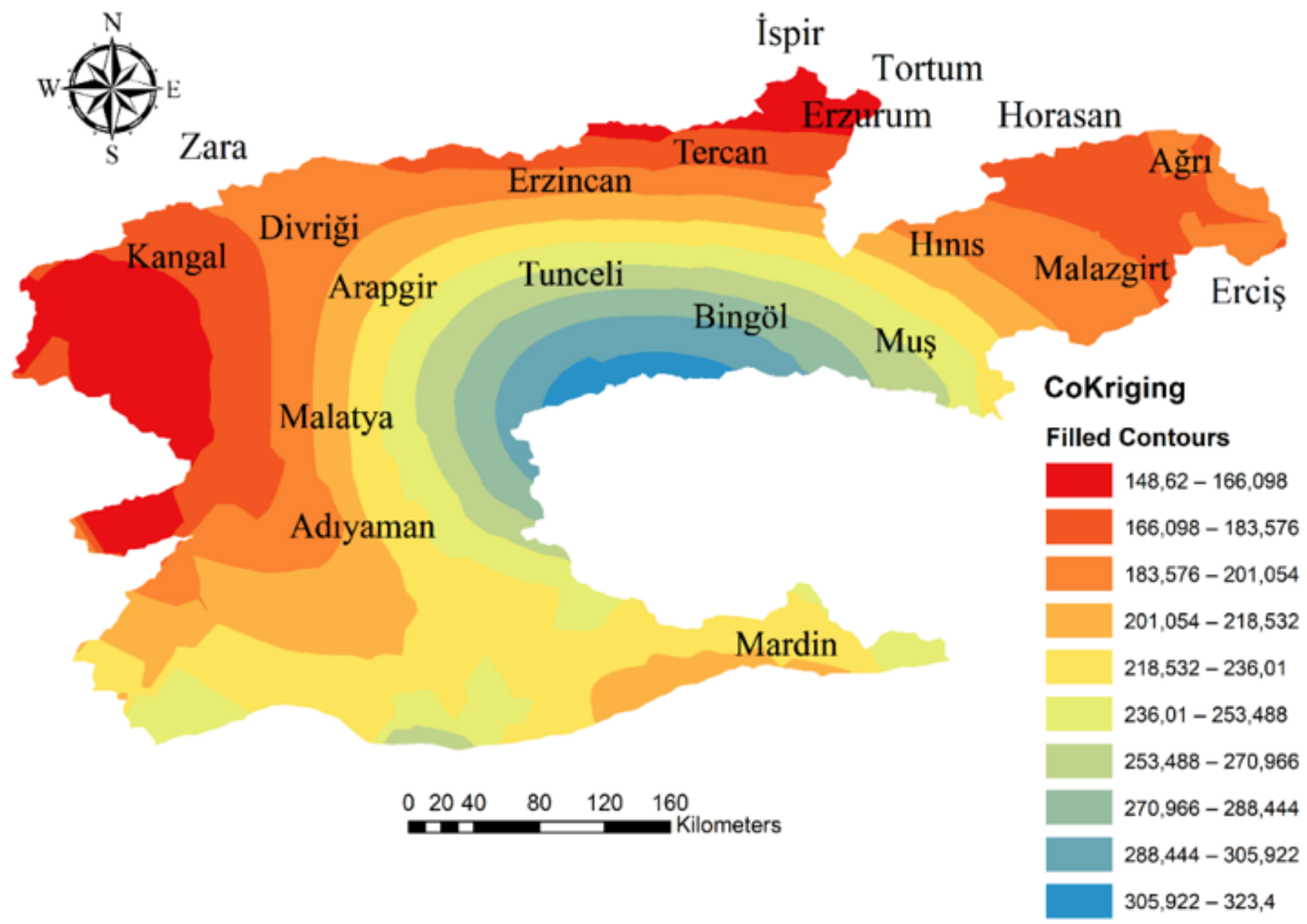

Figure 2

Mapping of spring precipitation with the OCK method 


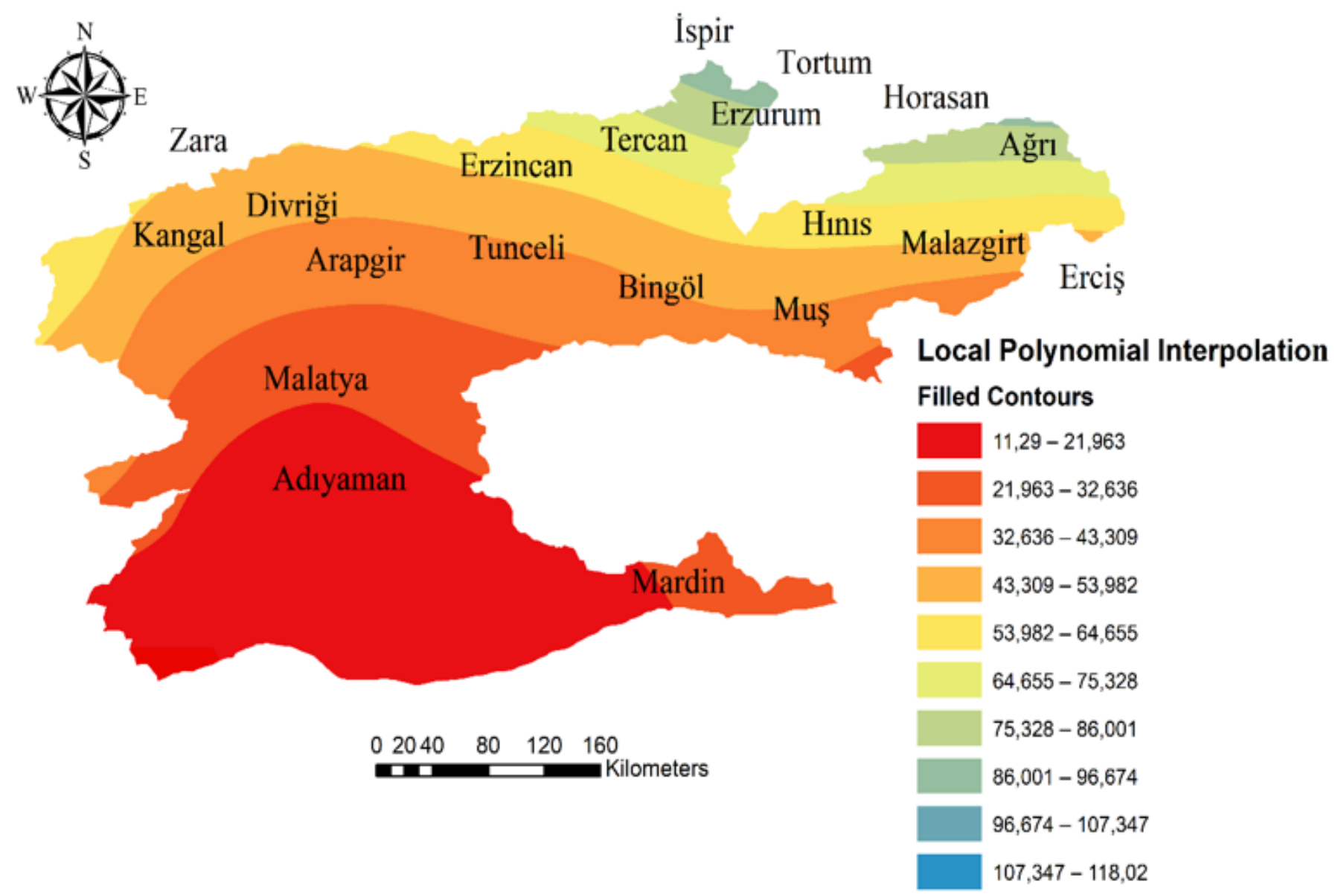

Figure 3

Mapping of summer precipitation with the LPI 


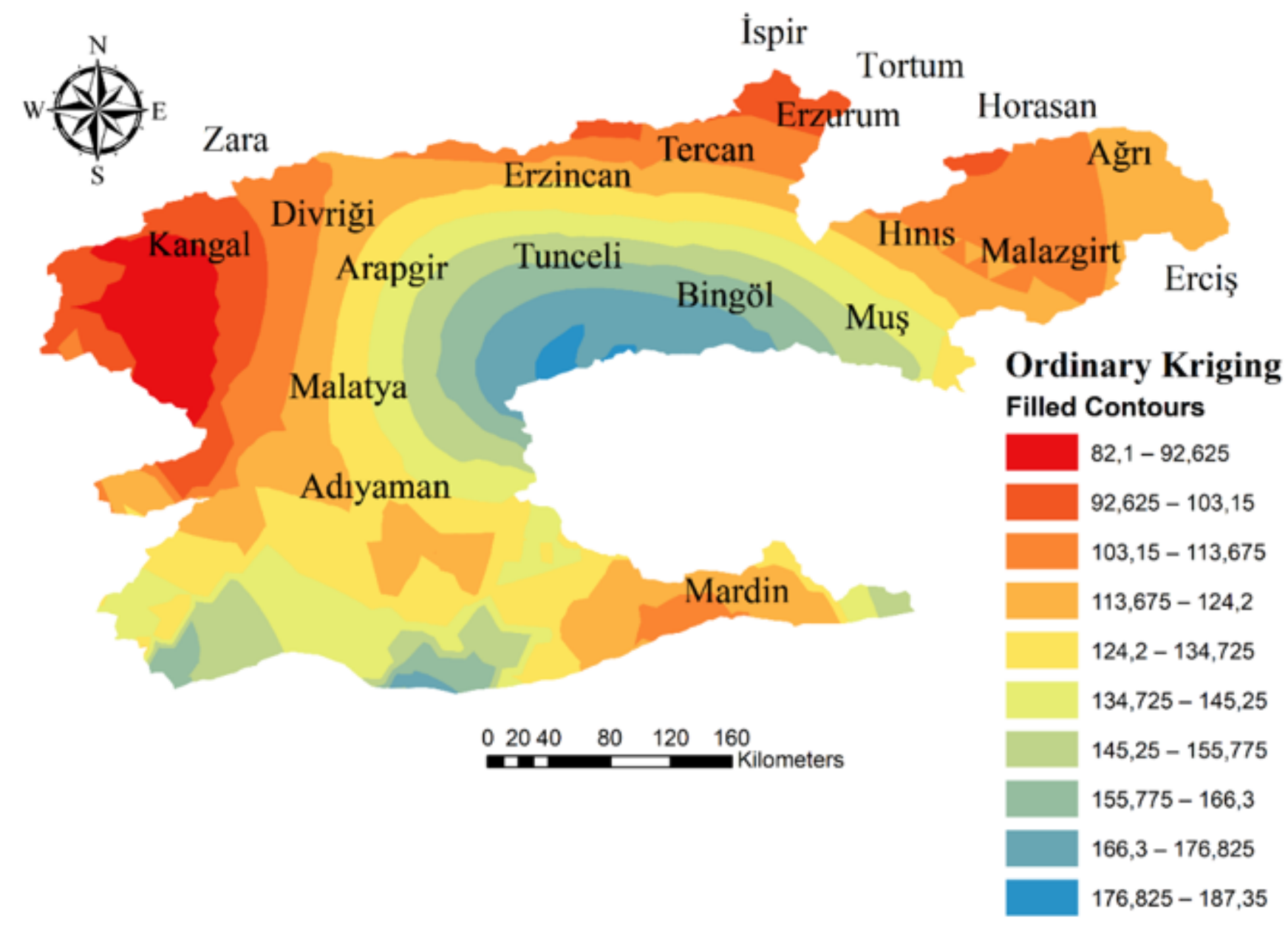

Figure 4

Mapping of autumn precipitation with the OK method 


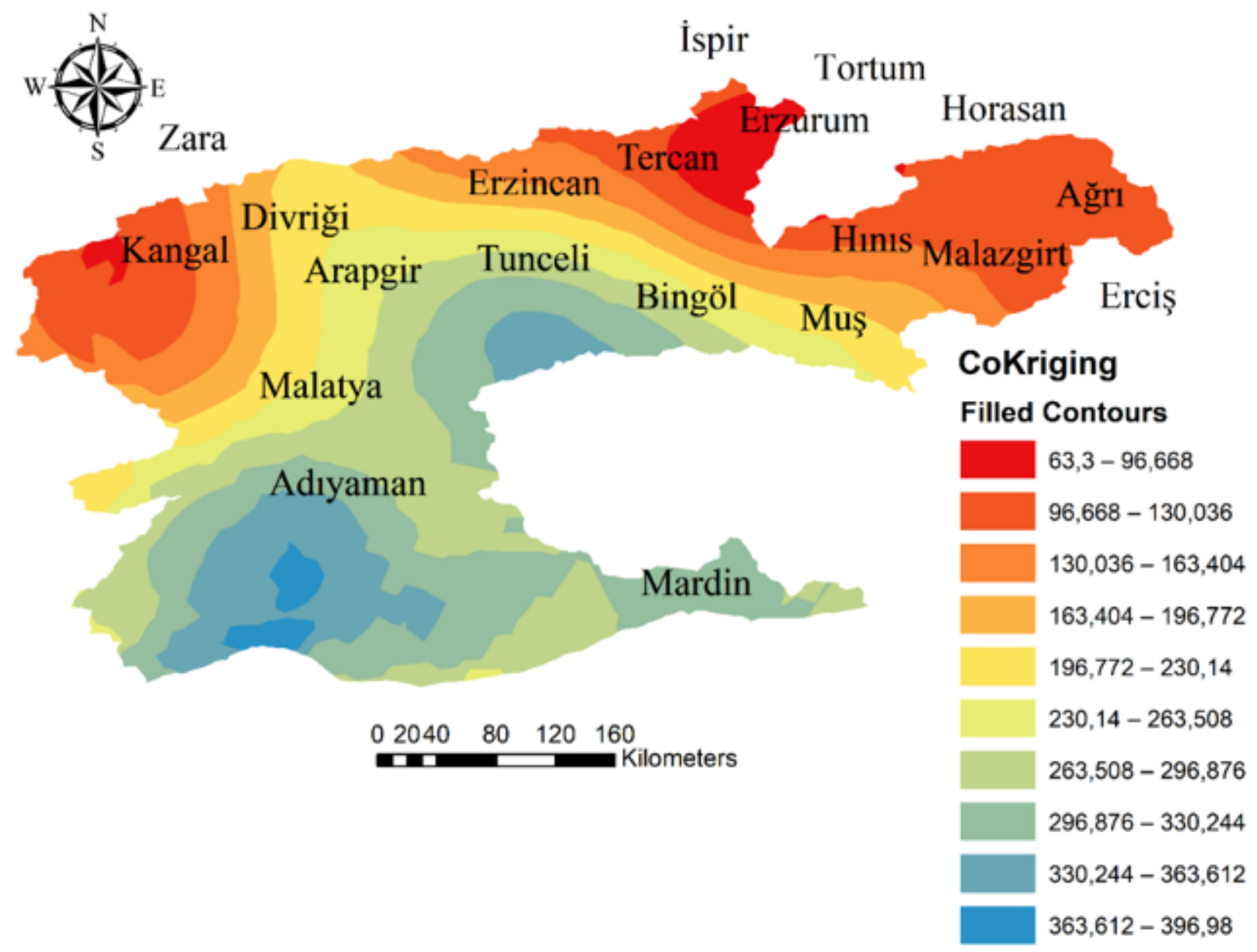

Figure 5

Mapping of winter precipitation with OCK method 